\title{
Isolation, characterization and identification of endophytic bacteria in maize (Zea mays L.) cultivated on Acrisols of the Southeast of Vietnam
}

\author{
Dang Thi Ngoc Thanh", , Cao Ngoc Diep ${ }^{2}$ \\ ${ }^{1}$ Dept. Natural Science Teacher Training, Sai Gon University, HCM city, Vietnam \\ ${ }^{2}$ Dept. Microbiology Biotechnology, Biotechnology R\&D Institute, Can Tho University, Can Tho City, Vietnam \\ Email address: \\ ngocthanh272002@yahoo.com (D. T. N. Thanh), cndiep@ctu.edu.vn (C. N. Diep)
}

\section{To cite this article:}

Dang Thi Ngoc Thanh, Cao Ngoc Diep. Isolation, Characterization and Identification of Endophytic Bacteria in Maize (Zea Mays L.) Cultivated on Acrisols of the Southeast of Vietnam. American Journal of Life Sciences. Vol. 2, No. 4, 2014, pp. 224-233.

doi: 10.11648/j.ajls.20140204.16

\begin{abstract}
Endophytic bacterial diversity in Maize plant cultivated on Acrisols of the Eastern of South Vietnam was studied. Maize material was collected from five sites (provinces/cities) of this region. Endophytic bacteria were isolated in two kinds of medium (LGI, NFb) together with 16S rRNA gene fragments amplified from DNA using eubacterial universal primers (p515FPL and p13B). A total of 301 isolates were isolated and all of them have ability of nitrogen fixation and phosphate solubilization together with IAA biosynthesis but there were 30 isolates having the best characteristics and they were identified as maize endophytes and nifH gene owners. The sequences from selected endophytic bacteria (30 isolates) showed high degrees of similarity to those of the GenBank references strains (between 97\% and 100\%). Among the selected isolates were 6 isolates belong to Bacillus $(20.00 \%)$ and 24 isolates belong to Proteobacteria (80.00\%) including 2 alpha-proteobacteria (7\%), 6 beta-proteobacteria (20\%), and 16 gamma-proteobacteria (53\%). Based on Pi value (nucleotide diversity), Proteobacteria group had the highest Theta values and Theta values (per sequence) from S of SNP for DNA polymorphism were calculated for each group and Proteobacteria group had the highest values in comparison of two groups. From these results showed that 3 isolates including DTN1b (Azotobacter vinelandii), VTN2b (Bacillus subtilis) and VTN7 (Enterobacter cloacae) proposed as potential microbial inoculants or biofertilizers for sustainable corn production in poor Acrisols in Vietnam because of their benefit and biosafety.
\end{abstract}

Keywords: Acrisols, 16S rRNA Gene Sequence, Endophytic Bacteria, Maize, the Eastern of South Vietnam

\section{Introduction}

Maize (Zea mays L.) is one of the oldest crops and is cultivated in many areas of the world. This grain is used in human food and in animal feed and for generating raw industrial materials [1]. To obtain high yields in most crops, as is particularly true in maize, it is necessary to apply mineral fertilizers to the soil, and this thing causes imbalance in natural ecosystems in addition to being one of the most expensive practices in agriculture as soil erosion, increase concentrations of nitrate in surface freshwater and groundwater and emissions of nitrous oxide during denitrification [2]. Microbial endophytic species are present in a wide range of plant species and reside either with cells [3], in the intercellular space [4], or in the vascular system
[5]. Endophytic bacteria are microorganisms that live in plant tissues [6] and they may be responsible for the supply of biologically fixed nitrogen to their host plant [7]. Endophytes also promote plant growth by a number of similar mechanisms as phosphate solubilization activity [8][9], indole acetic acid production [10] and the production of a siderophores [11].

The Eastern of South Vietnam is one of the two regions of South Vietnam, situated in the east of part of South Vietnam, lies between $10^{\circ} 20$ and $12^{\circ} 17^{\prime}$ north latitude and between $105^{\circ} 49^{\prime}$ and $107^{\circ} 35^{\prime}$ 'east longitude, covering 2.34 million ha, occupied about $20.3 \%$ of total of Vietnam area. This agroecological zone has the second largest area planted to maize in the country and most of maize is cultivated for commercial production. Maize is cultivated on diverse soils including gray soils and low-humic clay soil (haplic acrisols) 
[12]. Maize is the second crop (after rice) which provide food for human and an important source of income for many farmers in Vietnam. The maize fields mainly irrigated from rain water, and cultural practice has applied many kinds of chemical fertilizer (especially urea) as well as pesticides to obtain high grain yield because of low soil fertility [13] because maize production requires large amounts of nitrogen fertilizers, 9-11 kg $\mathrm{N}$ to produce 1 ton $\mathrm{ha}^{-1}$ [14]. Moreover, the use of chemicals, especially nitrogen, has high cost for farmers, which is the most frequent limiting factor for intensive agricultural production, this has led high cost of maize cultivation and low farmer's income.

In order to make maize cultivation sustainable and less dependent on chemical nitrogen fertilizers, it needs to be found the proportion of plant promoting bacteria, which are bacterial endophytes. The aims of this study were (i) isolation of maize endophytic bacteria, (ii) studying characteristic such as nitrogen fixation, phosphate solubilization and IAA production, (iii) the genetic diversity of endophytes isolated from maize plant was evaluated in order to identify an efficient growth promotion strains that can be also improve the growth of maize plant as biofertilizer.

\section{Materials and Methods}

\subsection{Sample Collection and Isolation of Endophytes}

sites of four provinces and one city (Tayninh, Dongnai, Binhduong, Baria-Vungtau and HochiMinh city) with a big area $(1,674,060 \mathrm{ha})$ and acrisols occupy a big area of these regions (Figure 1). Samples were obtained whole plant after that soil rhizosphere was separated for further experiments [15], maize roots were washed with tap water to remove attached clay; maize stem and root were cut separately. Subsequently, the stems and roots were immersed in $70 \%$ ethanol in $3 \mathrm{~min}$, washed with fresh sodium hypochlorite solution $(2.5 \%$ available $\mathrm{CT})$ for $5 \mathrm{~min}$, rinsed with $70 \%$ ethanol for $30 \mathrm{~s}$ and finally washed five times with sterile distilled water. To confirm that the sterilization process was successful, the aliquots of the sterile distilled water used in the final rinse were set on tryptic soy agar (TSA) medium plates. The plates were examined for bacterial growth after incubation at $28^{\circ} \mathrm{C}$ for 3 days. Maize stems and roots samples that were not contaminated as detected by culture-dependent sterility test were used for further analysis. Samples (stems or roots) were cut to $0.5-\mathrm{cm}$ pieces and macerated with a sterile mortar and pestle; tissue extracts were then serially (tenfold dilution) in sterile water, 200 $\mu$ l-aliquot samples were used to inoculate in (in triplicate) Nitrogen-free semisolid LGI, NFb in $5 \mathrm{ml}$ tubes. After 48-72 $\mathrm{h}$ incubation, bacteria growing in tubes as a white or yellow pellicle at a depth of 1 to $4 \mathrm{~mm}$ were streaked on LGI, NFb agar plates, cultures were streaked on media to obtain single colonies.

Plant samples (Zea mays L.) were collected from in 24

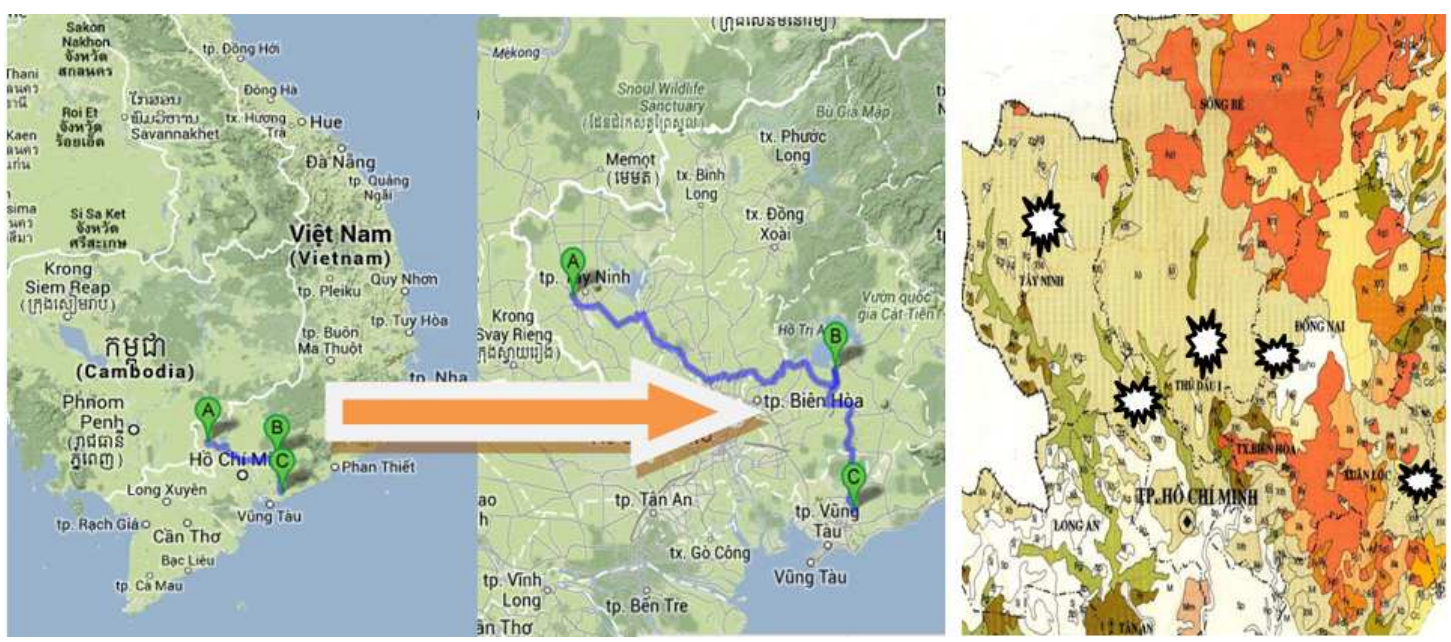

Figure 1. The geographic map and location of Acrisols, the Eastern of South Vietnam examined in this study and maize samples were collected at the these sites (5 provinces/cities)(Tayninh, Dongnai, Baria-VungTau, Binhduong, HCMcity)

Bacterial colonies were differentiated on the basis of colony morphology and pigmentation. Colonies were subculture on the agar-based subculture medium plates by striking technique and re-incubated at $30^{\circ} \mathrm{C}$ for 4 days. This isolation process carries out in shifts of the agar-based culture medium to the agar-based subculture medium until monocultures were obtained. Monocultures were culture on the agar-based culture medium slant in the test-tube $(12 \mathrm{ml})$ and incubated at $30^{\circ} \mathrm{C}$ for 4 days following by stored $10^{\circ} \mathrm{C}$ in refrigerator.

\subsection{Culture Media and Growth Conditions}

Isolation media was LGI [16], NFb [17]; for biofertilizer activities were Burk'N free [18], NBRIP [19].

\subsection{Colony Characteristic and Microscopic Examination}

The characteristics of colony such as size, color, shape... were presented in each group, cell morphologies of the isolates were observed using an optical microscope and they 
were also observed on scanning electron microscope.

\subsection{Screening for Biofertilizer Activities}

The ability to fix $\mathrm{N}_{2}$ was tested on Burk' $\mathrm{N}$-free liquid medium incubating at $30^{\circ} \mathrm{C}$ and the ammonium concentration in medium was measured by Phenol Nitroprusside method after 2,4,6 and 8 day inoculation (DAI) and inorganic phosphate solubilization ability was tested on NBRIP liquid medium and they were incubated at $30^{\circ} \mathrm{C}$ and the $\mathrm{P}_{2} \mathrm{O}_{5}$ concentration was measured by ammonium molypdate method. The qualitative detection of indole-3-acetic acid (IAA) production was carried out based on the colorimetric method [20]. Precultures were grown in Burk's $\mathrm{N}$ free $(100 \mathrm{ml})$ with $100 \mathrm{mg} / \mathrm{l}$ tryptophan in $250 \mathrm{~mL}$-flask at $30^{\circ} \mathrm{C}$ on a roller at $100 \mathrm{rpm}$ and samples were taken from at 2, 4, 6, and $8 \mathrm{DAI}$, cell free supernatants were mixed 2:1 with Salkowki reagent $\left(0.01 \mathrm{M} \mathrm{FeCl}_{3}\right.$ in $35 \%$ perchloric acid) and incubated in the dark for $20 \mathrm{~min}$ at RT. IAA-containing solutions were indicated by reddish color with an absorption peak at $530 \mathrm{~nm}$ on Genesys 10uv Thermo Scientific spectrophotometer.

\subsection{S rDNA Gene Amplification and Sequencing}

Bacterial DNA was isolated following published protocols [21]; The following primers were used for PCR amplification of $16 \mathrm{~S}$ ribosomal DNA: p515FPL [22] and p13B [23] [24]. The $50 \mu \mathrm{L}$ reaction mixture consisted of 2.5 $\mathrm{U}$ Taq Polymerase (Fermentas), $0.1 \mathrm{mM}$ of each desoxynecleotide triphosphate, $1.5 \mathrm{mM}$ magnesium chloride, $0.4 \mathrm{mM}$ spermidine (Sigma), $10 \mathrm{pM}$ of each primer (Fermentas) and $10 \mathrm{ng}$ DNA, 10\% (vol/vol) dimethyl disulfide (Fermentas). The thermocycling profide was carried out with an initial denaturation at $94^{\circ} \mathrm{C}$ (3 min) followed by 30 cycles of denaturation at $94^{\circ} \mathrm{C}(60 \mathrm{~s})$, annealing at $57^{\circ} \mathrm{C}(60 \mathrm{~s})$, extension at $72^{\circ} \mathrm{C}(120 \mathrm{~s})$ and a final extension at $72^{\circ} \mathrm{C}(4 \mathrm{~min})$ in $\mathrm{C} 1000$ Thermal Cycler (Bio-Rad). Aliquots $(10 \mu \mathrm{l})$ of PCR products were electrophoresed and visualized in $1 \%$ agarose gels using standard electrophoresis procedures. Partial 16S rRNA genes of selected isolates in each site were sequenced by MACROGEN, Republic of Korea (dna.macrogen.com). Finally, 16S rRNA sequence of the isolate was compared with that of other microorganisms by way BLAST (http://www.ncbi.nlm.nih.gov/BLAST/Blast.cgi). Among the best isolates (high ability of nitrogen fixation, phosphate solubilization and IAA synthesis) of 5 sites, 30 isolates were chosen to sequence and were compared to results with sequences of GenBank based on partial 16S rRNA sequences to show relationships between endophytic strains [25] and phylogenetic tree were constructed by the neighbor-joining method using the MEGA software version 6.06 based on 1000 bootstraps.

\subsection{PCR Amplification of the nifH Genes}

PCR amplification was performed to determine the presence of nifH gene using specific primers described by [26]. Amplification reaction were performed in a total volume of $25 \mu \mathrm{l}$. The reaction mixture contained: $2.5 \mu 110 \mathrm{x}$ PCR buffer, $2.5 \mu$ of $2 \mathrm{mM}$ each of dATP, dCTP, dTTP and dGTP, $3 \mu \mathrm{l}$ of each forward PolF (5'-TGCGYCCSAARGCBGACTC-3') and reverse PolR (5'-ATSGCCATYTCRCCGGA-3') primer (30 ng), $1 \mu \mathrm{l}$ of template DNA (10 ng) and $0.3 \mu \mathrm{l}$ of (3 U/1) Taq polymerase; final volume was made into $25 \mu \mathrm{l}$ using mili-Q water. The step-up PCR procedure included denaturation at $95^{\circ} \mathrm{C}$ for 3 min, $58^{\circ} \mathrm{C}$ for $1 \mathrm{~min}$, and $72^{\circ} \mathrm{C}$ for $1 \mathrm{~min}$, followed by 35 cycles of $95^{\circ} \mathrm{C}$ for $45 \mathrm{sec}, 58^{\circ} \mathrm{C}$ for $45 \mathrm{sec}$, and $72^{\circ} \mathrm{C}$ for 1 min, with a final extension at $72^{\circ} \mathrm{C}$ for $7 \mathrm{~min}$. Amplication products were electrophoreses on $1.5 \%$ agarose gel in $1 \mathrm{X}$ Tris-borate-EDTA (TBE) buffer.

\subsection{SNPs Discovery}

The sequence date from 30 endophytic bacterial isolates were analysed with SeqScape@Software (Applied Biosystem, Foster City, CA, USA). SeqScape is a sequence comparison tool for variant identification, SNP discovery and validation. It considers alignment depth, the base calls in each of the sequences and the associated base quality values. Putative SNPs were accepted as true sequence variants if the quality value exceeded 20 . It means a $1 \%$ chance basecall is incorrect.

\subsection{Nucleotide Diversity $(\theta)$}

Nucleotide diversity $(\Theta)$ was calculated by the method described by Halushka et al. [27]

$$
\theta=\frac{\mathrm{K}}{\mathrm{aL}} \mathrm{a}=\sum_{\mathrm{i}=2}^{\mathrm{n}} 1 /(\mathrm{i}-1)
$$

where $\mathrm{K}$ is the number of SNPs identified in an alignment length, $\mathrm{n}$ is alleles and $\mathrm{L}$ is the total length of sequence (bp).

\subsection{Data Analyses}

Data from ammonium, orthophosphate and IAA concentrations in media were analysed in completely randomized design with three replicates and LSD test at $\mathrm{P}=0.01$ were used to differentiate between statistically different means using SPSS version 16.

\section{Results and Discussion}

\subsection{Bacteria Isolation, Colony Characteristic and Microscopic Examination}

The endophytic bacteria developed in the pellicles of semisolid (in three kinds of medium) as the previous results of Weber et al. [28], Thu Ha et al. [29]. From 28 maize samples of 5 sites ( 5 provinces/city), 3 isolates were isolated on two kinds of medium (Table 1). 
Table 1. Total of isolates were isolated from maize material cultivated on Acrisols of 24 sites in 5 provinces/cities of the eastern of South Vietnam

\begin{tabular}{lllll}
\hline Site (province/city) & Maize sample & $\begin{array}{l}\text { Isolate numbers were } \\
\text { isolated from LGI medium }\end{array}$ & $\begin{array}{l}\text { Isolate numbers were } \\
\text { isolated from NFb medium }\end{array}$ \\
\hline \multirow{2}{*}{ Dongnai } & Stem & 26 & 19 & 21 \\
Total \\
Baria-Vungtau & Root & 14 & 19 & 45 \\
& Stem & 23 & 25 & 42 \\
Tayninh & Root & 17 & 36 & 51 \\
& Stem & 15 & 02 & 59 \\
Binhduong & Root & 28 & 02 & 03 \\
& Stem & 01 & 03 & 07 \\
HochiMinh city & Root & 05 & 04 & 08 \\
\hline
\end{tabular}

They developed very well on these media from $36-48 \mathrm{~h}$ at $30^{\circ} \mathrm{C}$, their colonies had round-shape, clammy, smooth, yellow, milk-color or colorless, and some colonies appeared to have much larger size (Figure 2). The cells were observed by SEM and appeared as rod and most of them have motility (Figure 3).

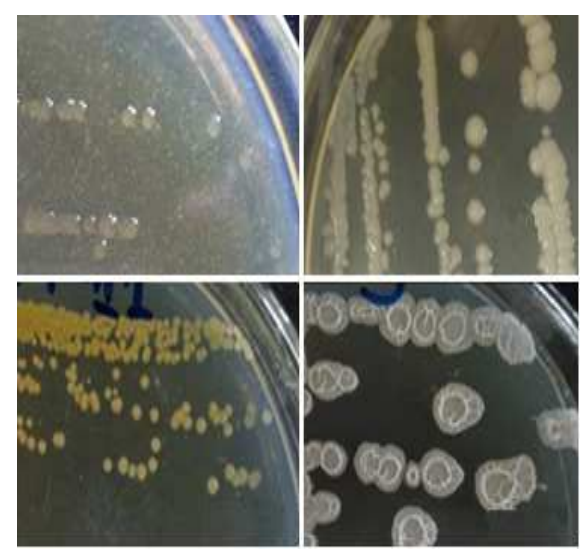

Figure 2. The colonies of several endophyte isolates from stems and roots of maize
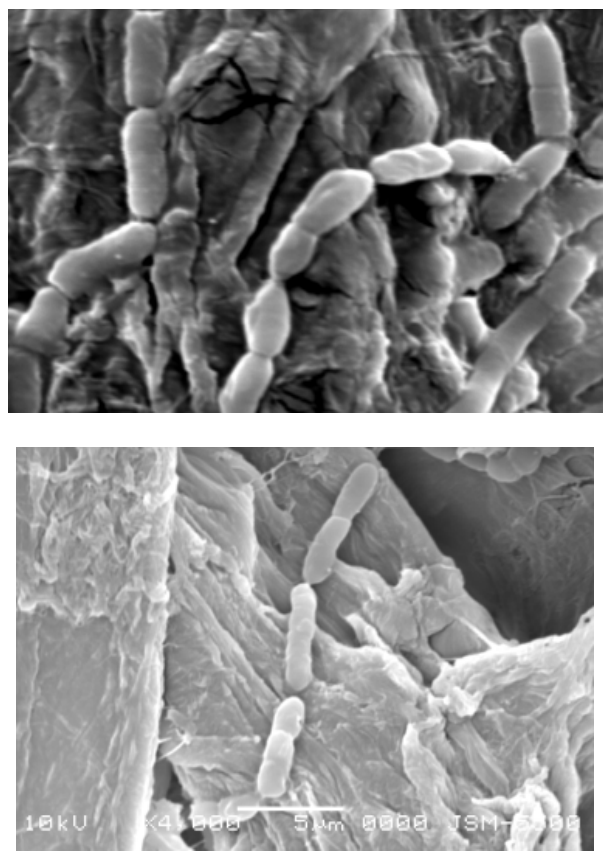

Figure 3. Electron micrographs of cells

\subsection{Screening for Biofertilizer Activities}

Table 2. Nitrogen fixation, phosphate solubilization and IAA synthesis production of 30 isolates

\begin{tabular}{|c|c|c|c|c|c|}
\hline No & Site & Isolate & $\begin{array}{l}\mathrm{NH}_{4} \\
(\mathrm{mg} / \mathrm{L}) \\
\end{array}$ & $\begin{array}{l}\mathrm{P}_{2} \mathrm{O}_{5} \\
(\mathrm{mg} / \mathrm{L}) \\
\end{array}$ & $\begin{array}{l}\text { IAA } \\
(\mathrm{mg} / \mathrm{L})\end{array}$ \\
\hline 01 & \multirow[t]{11}{*}{ BaRia-Vungtau } & VRL1b & 0.488 & 50.335 & 1.715 \\
\hline 02 & & VRN2b & 0.458 & 42.205 & 1.210 \\
\hline 03 & & VRL4b & 0.282 & 43.420 & 5.180 \\
\hline 04 & & VRL4c & 0.311 & 2.378 & 5.728 \\
\hline 05 & & VRL6c & 0.581 & 52.793 & 5.115 \\
\hline 06 & & VTL7a & 0.284 & 16.085 & 6.378 \\
\hline 07 & & VTN2b & 1.439 & 88.560 & 0.963 \\
\hline 08 & & VTN2c & 1.386 & 54.778 & 1.000 \\
\hline 09 & & VTN4c & 0.874 & 53.850 & 3.995 \\
\hline 10 & & VTN5a & 1.421 & 41.765 & 1.765 \\
\hline 11 & & VTN7 & 1.251 & 76.880 & 5.160 \\
\hline 12 & \multirow[t]{2}{*}{ Binhduong } & BRN1a & 0.326 & 46.075 & 3.320 \\
\hline 13 & & BTN1b & 1.079 & 48.995 & 8.170 \\
\hline 14 & \multirow[t]{2}{*}{ Dongnai } & DTN1b & 1.366 & 58.963 & 10.975 \\
\hline 15 & & DTN11 & 1.304 & 51.613 & 10.385 \\
\hline 16 & \multirow[t]{14}{*}{ Tayninh } & TRL1a & 1.195 & 25.010 & 11.733 \\
\hline 17 & & TRL5b & 0.283 & 49.315 & 11.383 \\
\hline 18 & & TRL6b & 0.296 & 51.935 & 14.580 \\
\hline 19 & & TRL6c & 0.915 & 41.753 & 11.310 \\
\hline 20 & & TRL6h & 0.364 & 88.200 & 11.140 \\
\hline 21 & & TRL6i & 0.257 & 49.498 & 11.255 \\
\hline 22 & & TRL7c & 0.254 & 61.316 & 10.598 \\
\hline 23 & & TRN6f & 0.453 & 63.733 & 8.973 \\
\hline 24 & & TRN6i & 0.318 & 81.890 & 8.640 \\
\hline 25 & & TRN7b & 0.391 & 85.053 & 11.478 \\
\hline 26 & & TTN2 & 2.211 & 72.553 & 2.978 \\
\hline 27 & & TTN4b & 1.474 & 68.223 & 3.365 \\
\hline 28 & & TTN4c & 2.686 & 59.858 & 3.485 \\
\hline 29 & & TTN13b & 2.274 & 49.615 & 3.640 \\
\hline 30 & \multirow[t]{4}{*}{ HCM city } & HTN1b & 1.851 & 48.833 & 9.710 \\
\hline \multirow[t]{3}{*}{31} & & Control & 0 & 0 & 0 \\
\hline & & LSD.01 & 0.149 & 7.641 & 1.092 \\
\hline & & C.V & $8.99 \%$ & $7.88 \%$ & $8.91 \%$ \\
\hline
\end{tabular}

Among 301 isolates, 30 isolates having good biofertilizer activity were chosen to study (Table 2). All 30 isolates have nitrogen fixation, phosphate solubilization ability) and all of them produced indole-3-acetic acid (IAA) in vitro. Several isolates have good plant growth activities as VTN2b, VTN2c, VTN5a, VTN7 (Baria-Vungtau), BTN1b (Binhduong), DTN1b, DTN11 (Dongnai), TTN2, TTN4b, TTN4c, TTN13b (Tayninh), and HTN1b (HCM city) (bold number in table 2). Endophytes increase plant growth through the improved cycling of nutrients and minerals such as nitrogen, phosphate and other nutrients [30]. Endophytes 
also promote plant growth by a number of similar mechanisms as phosphate solubilization activity [8][9], indole acetic acid production [10].

All of them ( 30 isolates) were chosen to identify and the fragments of $900 \mathrm{bp} 16 \mathrm{~S}$ rRNA were obtained from PCR and sequencing (Table 3 ), they are endophytic bacteria in maize.

The determination of nearest phylogenetic neighbor sequences for $16 \mathrm{~S}$ rRNA gene sequences of the 30 isolated by the BLAST search program showed that they grouped into two clusters (Figure 4). Cluster A divided two small cluters: cluster A1 with Pseudomonas taiwanensis VRL4c, Acinetobacter calcoaceticus HTN1b, Klebsiella vaniicola DTT11, Burkholderia vietnamiensis TRL7c, Bacillus thuringiensis TTN4c, Agrobacterium tumefasciens VRN2b have relationship closely while 3 strains Bacillus thuringiensis BTN1b, Pantoea dispersa VTL7a and
Burkholderia sp. had another relationship even though they were isolated from stems or roots of maize cultivated on Acrisols of Baria-Vungtau, Tayninh or Dongnai. In cluster A2 with 4 strains: Acinetobacter radioresistens TTN13, Azotobacter vinelandii DTN1b in a small cluster and Bacillus thuringiensis TTN4b and Bacilus subtilis VTN2b were very closely but they orinated from maize stems in Tayninh (TTN4b) and Baria-Vungtau (VTN2b).

Cluster B composed of two clusters: Cluster B1 had three strains but two strains (Burkholderia vietnamiensis VRL1b and Burkholderia ambifaria VRL6c) had a relationship closely because they were isolated on maize plant in Baria-Vungtau site; In cluster B21with two couples as Klebsiella vaniicola TRL5b and Enterobacter homaechei VTN5a and Bacillus thuringiensis TTN2 together with Enterobacter ludwigii VTN2c.

Table 3. Phylogenetic affiliation of isolates on the basis of $16 S$ rDNA genes sequences by using BLAST programme in the GenBank database based on sequence similarity

\begin{tabular}{|c|c|c|}
\hline Taxonomic group and strain & Closest species relative & Similarity $(\%)$ \\
\hline \multicolumn{3}{|l|}{ Bacilli } \\
\hline VTN2b & Bacillus subtilis strain pF2 (FJ614262) & 99 \\
\hline TRN7b & Bacillus thuringiensis strain VS1 (KF487306) & 99 \\
\hline TTN4b & Bacillus thuringiensis strain VITLW1 (KF971833) & 99 \\
\hline TTN4c & Bacillus thuringiensis strain DW-1T (EU240956) & 99 \\
\hline BTN1b & Bacillus thuringiensis strain T16-06 (GU143904) & 99 \\
\hline TTN2 & Bacillus thuringiensis strain zzx32 (KJ009430) & 99 \\
\hline \multicolumn{3}{|l|}{ Alphaproteobacteria } \\
\hline VRN2b & Agrobacterium tumefaciens strain G21-02 (GU143910) & 99 \\
\hline VRL4b & Agrobacterium tumefaciens strain T115 (FJ719343) & 99 \\
\hline \multicolumn{3}{|l|}{ Betaproteobacteria } \\
\hline VRL6c & Burkholderia ambifaria strain ChDC B361 (KF7336850 & 99 \\
\hline TRL6i & Burkholderia sp. FP8(2013) (KF623099) & 99 \\
\hline TRL7c & Burkholderia vietnamiensis strain C09V (JF922108) & 99 \\
\hline VRL1b & Burkholderia vietnamiensis strain WP25 (KF750606) & 99 \\
\hline TRL6c & Burkholderia sp. MN-TN3D3-E2 (JN975067) & 99 \\
\hline TRL6b & Burkholderia sp. BRRh-2 (KF921289) & 100 \\
\hline \multicolumn{3}{|l|}{ Gammaproteobacteria } \\
\hline TRN6f & Acinetobacter baumannii strain PHCDB16 (KF417546) & 99 \\
\hline HTN1b & Acinetobacter calcoaceticus strain 9 (KF923419) & 99 \\
\hline TTN13b & Acinetobacter radioresistens strain wx3 (KF963620) & 99 \\
\hline TRN6i & Acinetobacter sp. 150 (KC257011) & 99 \\
\hline DTN1b & Azotobacter vinelandii strain AAU11 (KF494186) & 99 \\
\hline TRL1a & Enterobacter aerogenes strain P5 (KF465841) & 99 \\
\hline TRL6h & Enterobacter asburiae strain m-4 (KF757336) & 98 \\
\hline VTN7 & Enterobacter cloacae strain B5 (DQ202394) & 99 \\
\hline VTN5a & Enterobacter hormaechei strain p66_G12 (JQ830569) & 99 \\
\hline VTN2c & Enterobacter ludwigii strain LHC8 (KC951920) & 99 \\
\hline BRN1a & Klebsiella sp. SCU-B85 (KJ000778) & 99 \\
\hline TRL5b & Klebsiella variicola strain RBEB5 (KF036186) & 99 \\
\hline DTN11 & Klebsiella variicola strain BCB2 (KF224905) & 99 \\
\hline VTN4c & Pantoea agglomerans strain T224 (KC764985) & 99 \\
\hline VTL7a & Pantoea dispersa strain REB6 (KF036181) & 98 \\
\hline VRL4c & Pseudomonas taiwanensis strain AVS1 (KF964670) & 99 \\
\hline
\end{tabular}




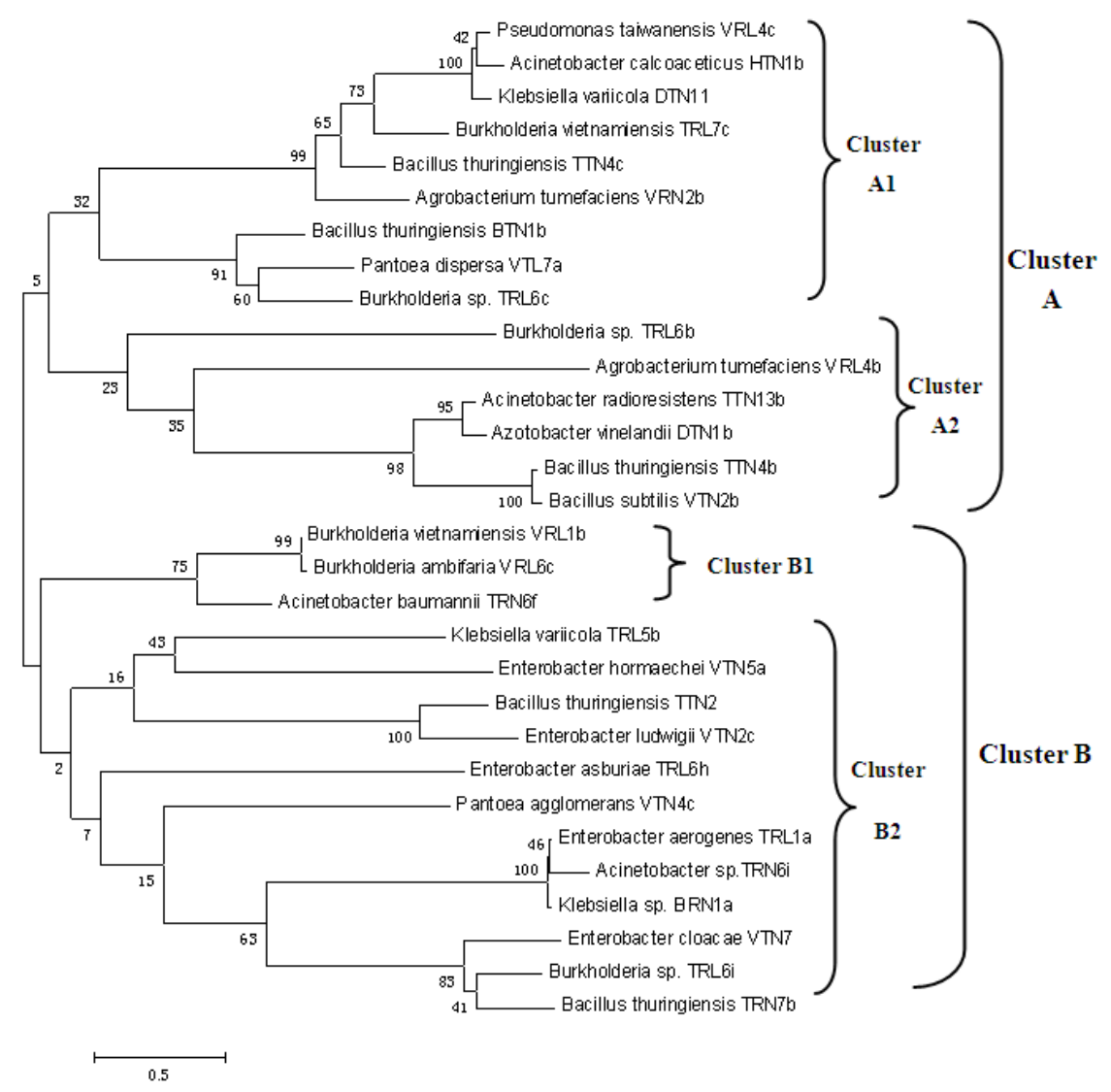

Figure 4. Phylogenetic tree for partial 16S rRNA gene sequences from 30 isolates by using primers (p515FPL, p13B) showing relationships between representative strains along with related sequences retrieved from GenBank. The numbers at the nods indicate the levels of bootstrap support (\%) based on a Neighbor-Joining analysis of 100 re-sampled datasets. The scale bar indicates the phylogenetic distance corresponding to 5 changes per 100 bases.

In cluster B22, except Pantoea agglomerans VTN4c strain, this cluster divided into two clusters among every cluster had three strains an Enterobacter aerogenes TRL1a, Acinetobacter sp. TRN6i, Klebsiella sp. BRN1a and Enterobacter cloacae VTN7, Burkholderia sp. TRL6i, Bacillus thuringiensis TRN7b, they were isolated from other sites but they had a genetic relationship closely. The bacterial endophytes has been studied and described as beneficial bacteria but these groups did not separate Gram-positive or Gram-negative bacteria for a long time however ratio of Gram-negative bacteria was higher than Gram-positive bacteria [31][32][33] and they were classified to Bacilli $(20.00 \%)$ and Proteobacteria $(80 \%)$ and the Proteobacteria group composed of Gamma-Proteobacteria (53.33\%), Beta-Proteobacteria $(20.00 \%)$ and Alpha-Proteobacteria (6.67\%) (Figure 5) in our result.

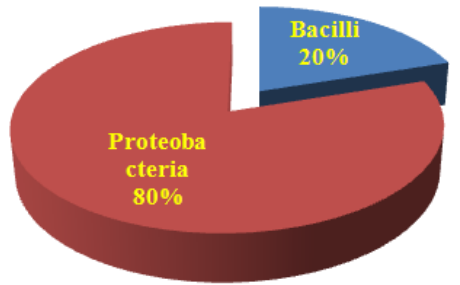

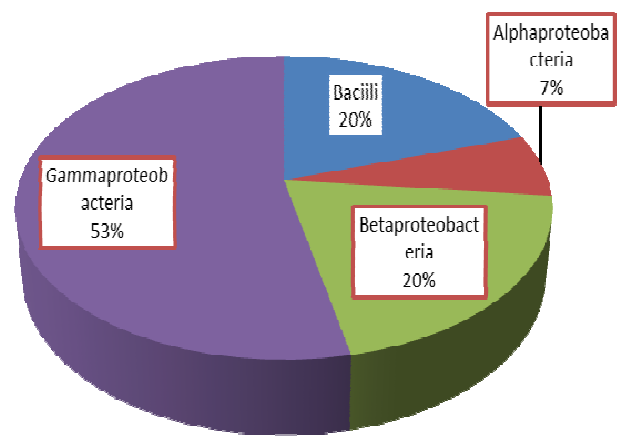

Figure 5. The proportion of group and they distributed in two clusters

Nucleotide polymorphism can be measured by many parameters, such as halotypes (genes) diversity, nucleotide diversity, $(\mathrm{Pi})$, Theta $(\Theta)$ (per group) etc... In this study, nucleotide diversity was estimated by Theta $(\Theta)$, the number of segregating sites [34], and its standard deviation (SO). These parameters were estimated by DNA Sequence Polymorphism software version 4.0 [35]. Pi values explained nucleotide diversity of sequences for each gene, the higher values, and the more diversity among groups. Proteobacteria group had the highest values and Bacilli group had the lowest values. Theta values (per sequence) from S of SNP for DNA polymorphism were calculated for each group, and Proteobacteria group had the highest values 
as comparison with Bacilli group (Table 4).

Table 4. Nucleotide diversity $(\theta)$ values of two EST's using the programme DNASp 5.0 [35]

\begin{tabular}{lllll}
\hline ESTs & Bacilli & Gamma proteobacteria & Beta proteobacteria & Alpha proteobacteria \\
\hline Nucleotide diversity $(\mathrm{Pi})$ & 0.03361 & 0.09397 & 0.01254 & 0.02445 \\
Theta (per sequence) from Eta & $31.971 \pm 14.002$ & $59.369 \pm 17.892$ & $9.635 \pm 4.220$ & $20.000 \pm 20.00$ \\
Nucleotide diversity (Pi) & 0.03361 & 0.70822 & & \\
Theta (per sequence) from Eta & $31.971 \pm 14.002$ & $156.65 \pm 6.447$ & & \\
Theta (per site) from Eta & & 0.79284 & & \\
\hline
\end{tabular}

Primer p515FPL 5'-GTGCCAGCAGCCGCGTAA-3' Primer p13B 5'-AGGCCCGGGAACGTATTCAC-3'

Haplotype analysis of 24 strains was presented in Figure 6. From this figure, it revealed that there was genetic diversity between two strains Agrobacterium tumefasciens VRN2b and VRL4b; Burkholderia vietnamiensis TRL7c and VRL1b, and Klebsiella variicola TRL5b and DTN11.

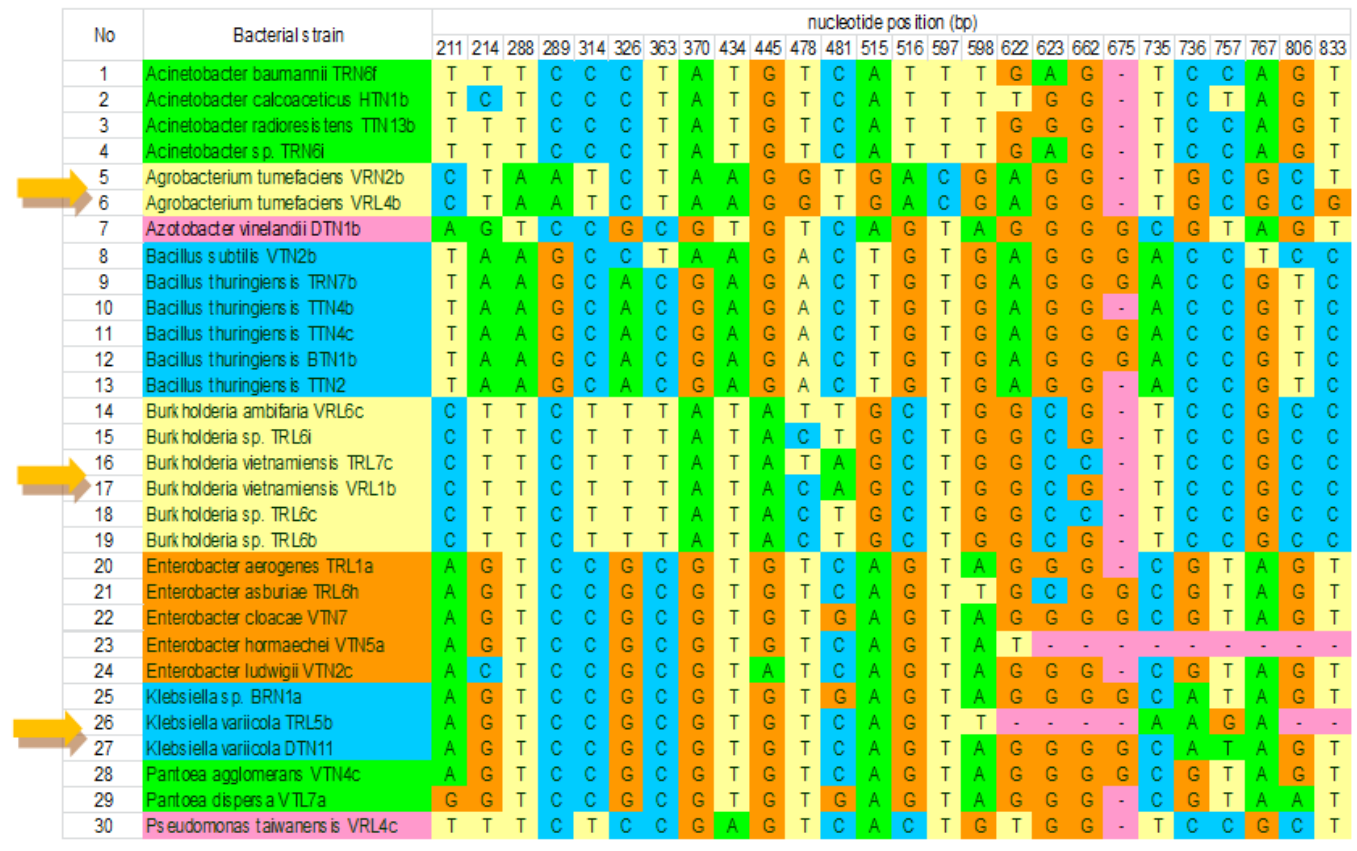

Figure 6. Haplotype analysis of 24 strains

\subsection{Amplication of nifH Gene}

To confirm the potential for nitrogen fixation, the presence of the structural gene for nitrogenase reductase (nifH) was determined by nifH gene amplication with genomic DNA extracted from 30 selected isolates (Figure 7). Amplication with the gene specific primers yielded the expected 360-bp bands on agarose gel however there were only 6 isolates among 30 isolates having the bands perhaps the Pol primers could not detect 24 to be left. This demonstrated these 6 strains are endophytes and nitrogen fixation ability on maize cultivation in Acrisols. Szilagyi-Zecchin et al. [36] based on sequencing of the $16 \mathrm{~S}$ rRNA gene revealed the presence of endophytic bacteria in maize planted in Bzazil belonging to the genera Bacillus (6/10 strains) and Enterobacter (4/10 strains). Among 10 strains were one strain was positive for nifH gene amplication (Bacillus sp. CNPSo 2478) resulted in a fragment of about $400 \mathrm{bp}, 2$ strains were positive with PCR primers nifHF and nifHI producing the bands of about 700 bp (Bacilli CNPSo 2477 and 2476), and one strain
(Enterobacter sp. CNPSo 2480) was positive for the two pairs of both primers tested (nifH-F and nifH-R, nifHF and nifHI) [36]. As the our result of rhizospheric bacteria [14], there were 6 Gram-positive Bacilli strains in total of 24 rhizosphere bacteria of maize, these showed that Gram-negative bacteria were dominant in rhizosphere and endophytic bacteria in maize cultivated in Acrisols of the South Vietnam.

\section{$\begin{array}{llllllll}M & 1 & 2 & 3 & 4 & 5 & 6 & \text { control }\end{array}$}

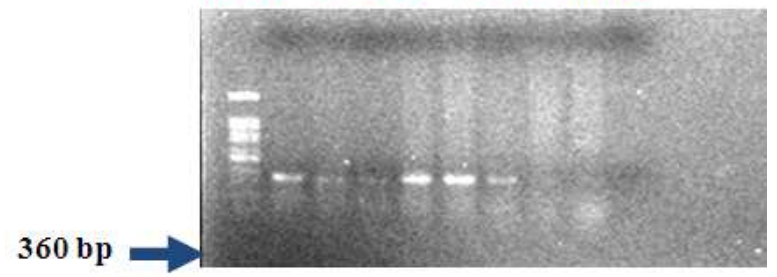

Figure 7. Agarose gel gel electrophoresis of PCR products obtained by amplifying nifH gene from genomic DNA of bacterial isolates. M, marker 100bp DNA ladder, 1-6 were 6 strains among 30 strains. 
Microbial endophytic species are present in a wide range of plant species and reside either within cells [3], in the intercellular space [4], or in the vascular system [5] of the plant. Recent reports have confirmed this view, and bacterial endophytic species have been implicated in the promotion of plant growth and protection against pathogens [37][38]. Beneficial rhizospheric and endophytic associations that occur with the roots of gramineae plants with bacteria include those with capacity of fixing atmospheric nitrogen $\left(\mathrm{N}_{2}\right)$ and promoting plant growth [39]. McInroy and Kloepper [40] found that the most frequently isolated members of the endophytic bacterial community in maize are Enterobacter spp. (members of Gamma-proteobacteria), followed by the beta-proteobacterial Burkholderia spp., and Seghers et al. [41] discovered Gram-negative bacteria (Gamma-proteobacteria) including Enterobacter sp., Pseudomonas sp., Rahnella aquatilis in roots and kernels of maize cultivated on soil of Melle, Belgium using DGGE analysis and endophytes were found in stems of maize cultivating soil of India, Bacillus sp. and Pseudomonas sp. using Gas Chromatography - Fatty Acid Methyl Ester (GC-FAME) [42] and Roesch et al. [43] also found that rhizospheric and endophytic bacteria in soil, root and stem of field-grown maize in Brasil were alpha, beta and gamma-proteobacteria and recent results of Ikeda et al. [39] showed that endophytic bacteria in maize (in Brazil) belonged to the genera Pantoea, Bacillus, Burkholderia and Klebsiella and and our results were the same as previous studies of endophytic bacteria in maize in the world.

Based on bio-safety and good characteristics, this study selected 3 strains as Azotobacter vinelandii DTN1b, Bacillus subtilis VTN2b, Enterobacter cloacae VTN7 to evaluate their effects on maize cultivated on Acrisols in pot-experiment and the field trial.

\section{Conclusion}

From 28 field-grown maize samples on Acrisols in 5 provinces/city of the Eastern of the South Vietnam, 301 isolates were isolated and identified as maize endophytes and 30 isolates having good plant growth promotion were chosen to analyse their relationship. These isolates showed that bacterial diversity was very high. Among them, there are 3 strains will be suggested to produce biofertilizer for maize cultivation on Acrisols in the future.

\section{Acknowledgements}

The authors thank the help of Microbiology BSc. Students and technicians in the Environment Microbiology Laboratory, Biotechnology R\&D Institute, Can Tho University, Vietnam; especially Associate Professor Dr. TRUONG TRONG NGON, Head of Molecular Biotechnology Department, Biotechnology R\&D Institute, Can Tho University, Vietnam for analysing molecular data.

\section{References}

[1] L. Arruda, A. Beneduzi, A. Martin, B. Lisboa, C. Lopes, F. Bertolo, L. M. P. Passaglis, and L.K. Vargas, "Screening of rhizobacteria isolated from maize (Zea mays L.) in Rio Grande do Sul State (South Brasil) and analysis of their potential to improve plant growth," Applied Soil Ecology, vol. 63 , pp. 15-22, 2013.

[2] I.R. Kennedy, A.T.M.A. Choudhury, and M.L. Kecskes, "Non-symbiotic bacterial diazotrophs in crop-farming systems: can their potential for plant growth promotion be better exploited? Soil Biol. Biochem., vol. 36, pp.129-1244, 2004.

[3] M.J. Jacobs, W.M. Bugbee, and D.A. Gabrielson, "Emuration, location, and characterization of endophytic bacteria within sugar beet roots," Can.J. Botany., vol.63, pp.1262-1265, 1985.

[4] D.G. Patriquin and J. Dobereiner, "Light microscopy observation of terrazolium-reducing bacteria in the endorhizosphere of maize and other grasses in Brasil," Can. J. Microbiol., vol.24, pp.734-742, 1978.

[5] C.R. Bell, G.A. Dickie, W.L.G. Harvey, and J.W.Y.F. Chan, "Endophytic bacteria in grapevine," Can. J. Microbiol., vol. 41, pp.46-53, 1995.

[6] J.I. Baldani, L. Caruso, V.L.D. Baldani, S.R. Goi, and J. Dobereiner, "Recent advances in BNF with non-legume plants," Soil. Biol. Biochem., vol. 29, pp.911-922, 1997.

[7] R.M. Boddey, .C. de Oliveira, S. Urquiaga, V.M. Reis, F.L. de Olivares, V.L.D. Baldani, and J. Dobereiner, "Biological nitrogen fixation associated with sugarcane and rice: Contributions and Prospects for improvement," Plant Soil, vol.174, pp.195-209, 1995.

[8] S.C. Verma, J.K. Ladha and A.K. Tripathi, "Evaluation of plant growth promoting and colonization ability of endophytic diazotrophs from deep water rice," J. Biotechnol., vol. 91, pp.127-141, 2001.

[9] S, Wakelin, R. Warren, P. Harvey and M. Ryder, "Phosphate solubilization by Penicillium spp. closely associated with wheat roots," Bio. Fert. Soils, vol. 40, pp.36-43, 2004.

[10] S. Lee, M. Flores-Encarnation, M. Contreras-Zentella, L. Garcia-Flores, J.E. Escamilla and C. Kennedy, "Indole-3-acetic acid biosynthesis is deficient in Gluconacetobacter diazotrophicus strains with mutations in cychrome C biogenesis genes," J. Bacteriol., vol. 186, pp.5384-5391, 2004.

[11] J.M. Costa and J.E. Loper, "Characterization of siderophore production by the biological-control agent Enterobacter clocae," Mol. Plant Microbe. Interact., vol.7, pp.440-448, 1994.

[12] T.D. Ha, T.D. Thao, N.T. Khiem, M.X. Trieu, R.V. Gerpacio, and P.L. Pingali, "Maize in Vietnam: Production Systems, Constraints, and Research Priorities", Mexico, D.F.: CIMMYT, 2004.

[13] L.H. Ba, "Vietnam Soil Resource," Education Publishing House, Vietnam, 2009. 
[14] A.R. Anuar, Z.H. Shemsuddin, and O. Yaacob, "Contribution of legume-N by nodulated groundnut for growth of maize on an acid soil," Soil. Biochem., vol.27, pp.595-601. doi:1016/0038-0717(95)98637-4.

[15] D.T.N. Thanh, and C.N. Diep, "Isolation and identification of rhizospheric bacteria in Acrisols of maize (Zea mays L.) in the eastern of South Vietnam. American Journal of Life Sciences. vol. 2, No. 2, pp.82-89, 2014. doi: 10.11648/j.ajls.20140202.18 (online). ISSN 2328 - 5737.

[16] V.A. Cavalcante and J. Dobereiner, "A new acid tolerant nitrogen fixing bacterium associated with sugarcane," Plant Soil, vol. 108, pp.23-31, 1988.

[17] G. Kirchhof, V.M. Reis, J.J. Baldani, B. Eckert, J. Dobereiner, and A. Hartmann, "Occurrence, physiological and molecular analysis of endophytic diazotrophic bacteria in gramineous energy plants," Plant Soil, vol. 194, pp.45-55, 1997.

[18] M. Park, C. Kim, J. Yang, H. Lee, W. Shin, S. Kim and T. Sa, "Isolation and characterization of diazotrophic growth promoting bacteria from Gram rhizosphere of agricultural crops of Korea," Microbiological Research, vol 160, pp. 127-133, 2005.

[19] C.S. Nautiyal, "An efficient microbiological growth medium for screening phosphate-solubilizing microorganisms," FEMS Microbiology Letters, vol. 170, pp.256-270, 1999.

[20] S.A. Gordon and R.P. Weber., "Colometric estimation of indolacetic acid," Plant Physiol., vol 26, pp.192-195, 1951.

[21] B. Neumann, A. Pospiech, and H.U. Schairrer, "Rapid isolation of genomic DNA from Gram-negative," Trends Gent., vol. 8, pp. 332-333, 1992.

[22] D.A. Relman, T.M. Schmidt, E.P. MacDermontt, and S. Falkow, "Identification of the uncultured bacillus of Whipple's disease,” N. Engl. J. Med., vol. 327, pp.293-301, 1992.

[23] D.A. Relman, J.S. Loutit, T.M. Schmidt, S. Falkow, and L.S. Tompkin, "The agent of bacillary angiomatosis. An approach to the identification of uncultuted pathogens," N. Engl. J. Med., vol. 323, pp.1573-1580, 1990.

[24] K.D. Zinniel, P. Lambercht, N.B. Harris, Z. Feng, D. Kuczmarshki, P. Higley, C.A. Ishimaru, A. Arunakumari, R.G. Barletta, and A.K. Vidaver, "Isolation and charcaterization of endophytic bacteria from agronomic crops and prairie plants," Appl. Environ. Microbiol., vol. 68, pp. 2198-2208, 2002.

[25] K. Tamura, D. Peterson, N. Peterson, G. Stecher, M. Nei, and S. Kumar, "MEGA5: Molecular Evolutionary Genetics Analysis using Maximum Likehood, Evolutionary Distance and Maximum Parsimony Methods," Mol. Biol. Evol., vol. 28, pp. 2731-2739, 2011.

[26] F. Poly, L.M. Joteur, R. Bally, "Improvement in RELP procedure to study the community of nitrogen fixers in soil through the diversity of nifH gene." Res. Microbiol., vol. 152, pp. 95-103, 2001.

[27] M.K. Halushka, J.B. Fan, K. Bentley, L. Hsie, N. Shen, A. Weder, R. Cooper, R. Lipshutz, and A. Charavarti, "Patterns of single-nucleotide polymorphisms in candidate genes for blood-pressure homestasis," Nat. Genet., vol. 22(3), pp. 239-247, 1999.
[28] O.B. Weber, V.L.D. Baldani, K.R.S. Teixeira, G. Kirchof, J.I. Baldani, and J. Dobereiner, "Isolation and characterization of diazotrophic bacteria from banana and pineapple plants," Plant and Soil., vol 210, pp. 103-113, 1999.

[29] N.T.Thu Ha, H.T. Toan, C.N.Điep, "Isolation anf characrterization of endophytic bacteria in several forage grass cultivars," J. Biotechnology., vol. 7(2), pp.241-250, 2009.

[30] R.P. Ryan, K. Germanie, A. Franks, D. J. Ryan and D.N. Dowling, "Bacterial endophytes: recent developments and applications,” FEMS Microbiol. Lett., vol. 278, pp.1-9, 2008.

[31] D.Y. Kobayashi, and J.D. Palumbo, "Bacterial Endophytes and Their Effects on Plants and Uses in Agricultulture," C.W. Bacon and J.F. White. Eds, Marcel Dekker, New York, 2000.

[32] C. Lodewyckx, J. Vangronsveld, F. Porteous, E.R.B. Moore, S. Taghavi, M. Mezgeay and D. van der Lelie, "Endophytic Bacteria and Their Potential Applications," Critical Reviews in Plant Sciences, vol. 21 (6), pp. 583-602, 2002.

[33] A. Montanez, A.R. Blanco, C.Barlocco, M. Beracochea, and M. Sicardi, "Characterization of cultivable putative endophytic plant growth promoting bacteria associated with maize cultivars (Zea mays L.) and their inoculation effects in vitro," Applied Soil Ecology, vol.58, pp.21-28, 2012.

[34] G.A. Watterson, "On the number of segregation sites in general models without recobination," Theor. Pop. Biol., vol. 7, pp. 256-276, 1975.

[35] J. Rozas, and R. Rozas, "DnaSP version 4.1: an integrated program for molecular population genetics and molecular evolution analysis," Bioinformatics, vol. 15, pp. 174-175, 2005.

[36] V. J. Szilagyi-Zecchin, A. C. Ikeda, M. Hungria, D. Adamoski, V. Kava-Cordeiro, C. Glienke, and L. V. Galli-Terasawa, "Identification and characterization of endophytic bacteria from corn (Zea mays L.) roots with biotechnological potential in agriculture", AMB Express, vol.4(26). Published online: 7 May 2014. doi: 10.1186/s13568-014-0026-y.

[37] N. Benhamou, S. Gagne, D. Le Quere, and E.M. Top, "Bacterial mediated induced resistance in cucumber: beneficial effect of the endophytic bacterium Serratia phymuhica on the protection against infection by Pythium ultimum," Phytopathology, vol. 90, pp.45-56, 2000.

[38] A.V. Sturz, and J. Nowak, "Endophytic communities of rhizobacteria and the strategies required to create yield enhancing associations with crops," Appl. Soil. Ecol., vol.15, pp.183-190, 2000.

[39] A.C. Ikeda, L.L. Bassani, D. Adamoski, D. Stringari, V.K. Cordeiro, C. Glienke, M.B. R. Steffens, M. Hungaria, L.V. Galli-Terasawa, "Morphological and genetic characterization of endophytic bacteria isolated from roots of different maize genotypes," Microb. Ecol., vol. 65, pp.154-160, 2013.

[40] J.A. McInroy, and J.W. Klorpper, "Survey of indigenous bacterial endophytic from cotton and sweet corn," Plant Soil, vol. 173, pp.337-342, 1995.

[41] D. Seghers, L. Wittebolle, E.M. Top, W. Verstraete, and S.D. Siliano, "Impact of Agricultural Practices on the Zea mays L. Endophytic Community," Appl. Environ. Microbiol., vol.70(3), pp. 1475-1482, 2004. 
[42] R. Rai, P.K. Dash, B.M. Prasanna, and A. Singh,’Endophytic bacterial flora in the stem tissue of a tropical maize (Zea mays L.) genotype: isolation, identification and enumeration," World J. Microbiol. Biotechnol.., vol. 23, pp. 853-858, 2007.
[43] L.F.W. Roesch, F.A.O. Camargo, F.M. Bento, and E.W. Triplett, "Biodiversity of diazotrophic bacteria within the soil, rott and stem of field-grown maize," Plant Soil, vol.302, pp.91-104, 2008. 